through the Ministry of Supply and the Scottish Education Department. In cases where service apparatus could not be used in schools without adaptation, methods of doing this were demonstrated.

Mr. F. A. Meier, of the London Institute of Education, gave two lecture-demonstrations on the construction and use of scientific apparatus, and lectures were given by Prof. J. W. Cook, on "The Effects of Some Chemical Compounds on the Growth of Cells", by Prof. P. I. Dee, on "The Elementary Particles of Matter", and by Dr. H. F. Steedman, on "Practical Methods in Zoology".

At a discussion on "School and University Teach. ing", the chair was taken by Sir Hector Hetherington, and leading parts were taken by Prof. J. Walton, Prof. W. M. Smart and Mr. F. G. Daldy, of Trinity College, Glenalmond. Many other members of the Association joined in the discussion, and in response to suggestions put forward steps have been taken to promote a closer liaison between Scottish members of the Science Masters' Association and the faculties of science in the Scottish universities.

At the annual business meeting, Mr. H. S. Sowrey, Glasgow Academy, was elected chairman of the Branch in succession to Mr. W. J. Lodge, Fettes College. The joint secretaries are F. G. Daldy, Trinity College, Glenalmond, and J. Wallace, Melville College, Edinburgh, and the treasurer is W. P. D. Wightman, Edinburgh Academy.

\section{A I50-TON UNIVERSAL STRUCTURE TESTING MACHINE}

$\mathrm{W}$ . AND T. AVERY, LTD., of Birmingham have recently designed and built a 150-ton universal structure testing machine for Short Bros. and Harland, Ltd. (Engineer, December 26, pp. 594-596).

It is significant that it is no longer considered sufficient to carry out tests on the material from which a complicated structure is made, and to base design upon calculations made from the results of such tests alone. There is a growing need to apply as near full-scale tests as possible. Geometrical similarity in test-pieces tested under laboratory conditions show a dimensional effect which it is often difficult to explain, except by assuming an anisotropy or inhomogeneity of the material. It is still more difficult to predict the behaviour of a material under complicated stress distributions from the results of the standard mechanical tests carried out on carefully prepared samples of shapes designed to make the interpretation of the results as simple as possible.

The new Avery machine can accommodate specimens up to $9 \mathrm{ft} .9 \mathrm{in}$. long in tension and $15 \mathrm{ft}$. in compression, while it can also be adapted for carrying out transverse tests on specimens up to $7 \mathrm{ft}$. span.

The tension and compression units are separate. They are, in fact, two testing machines but having a common hydraulic oil pump for applying loads and a dynamometer and indicator cabinet which can be used with either. The advantages to be gained by the separate units are that the effective height is greater, so that longer specimens may be used; and although the two units cannot be used simultaneously, setting-up can proceed in one while testing goes on in the other. This is an important consideration when it is desired to attach the large number of strain gauges often required for the full interpretation of complicated sections or built-up structures.
Against the separation of the testing units must be set one disadvantage, namely, the far greater space occupied by the whole machine.

The method of operation and load recording is similar to previous machines made by Avery's and to other machines of this type. There are four loadranges : $0-150$ tons in increments of 0.5 ton being the highest and $0-15$ tons in increments of 0.05 ton the lowest. It is doubtful whether a machine of this capacity can, in fact, be used with any degree of accuracy on the lower range, and it would appear to be preferable to omit this range entirely and to use the machine for the purpose for which it was designed and for which it is eminently suitable.

C. F. TrPper

\section{GROWTH-PROMOTING SUBSTANCES IN HORTICULTURE}

A CONCISE review by Dr. T. Swarbrick of recent A developments in the application of growthpromoting substances in horticulture, with special reference to the researches carried out at Long Ashton since 1939, appears in Occasional Publications on Scientific Horticulture No. 5 (published by the Horticultural Education Association, c/o Gibbs and Sons, 16 Orange Street, Canterbury, Kent). Present applications include the acceleration of rooting in cuttings, the prevention of pre-harvest drop in apples and pears, the induction of parthenocarpic development in tomato and other plants, and finally their employment as selective weed killers.

Parthenocarpic fruits of apple and pear have been obtained with certain varieties but not with others, employing 2.4 dichloro-phenoxy-acetic acid, 2.6 dichloro-phenoxy-acetic acid and also beta-naphthoxyacetic acid. In all cases, however, the artificially 'set' fruit grew slowly and never attained normal size. Similar development was induced in Miller's seedling apple and Conference pear following frost damage to the 'set' fruit during the spring of 1945. Betanaphthoxy-acetic acid has also proved effective in inducing a very marked increase in 'set' and yield of the self-sterile varieties of strawberry, Tardive de Leopold and Oberschlesien.

Two interesting lines of investigation are suggested by the fact that crude extracts of the flowers have been found to induce parthenocarpic development in tomato, and secondly, that stilbœstrol, a synthetic œestrogen of high potency in animals, is similarly effective. Certain of these growth substances, when used at concentrations higher than that required to induce parthenocarpy, produce modification of leaf shape and venation and clearing of the veins closely simulating many characteristic symptoms of virus infection. This raises interesting conjectures concerning the nature of the action of virus on host. The effect of tri-iodo-benzoic acid in modifying lateral and terminal vegetative shoots of tomato to form flower trusses constitutes an interesting parallel to the suspected action of naturally occurring hormones which are believed to initiate the formation of flower primordia.

The progress already achieved in this field suggests that a joint attack by biochemist and plant physiologist may be expected to lead to a rapid expansion in our knowledge of the biochemical control of development and reproduction in plants. 